\title{
Response of Bell Pepper Cultivars to Bacterial Spot Pathogen Races that Individually Overcome Major Resistance Genes
}

\author{
C. S. Kousik and D. F. Ritchie, Department of Plant Pathology, North Carolina State University, Raleigh 27695- \\ 7616
}

\begin{abstract}
Kousik, C. S., and Ritchie, D. F. 1998. Response of bell pepper cultivars to bacterial spot pathogen races that individually overcome major resistance genes. Plant Dis. 82:181-186.

The effect of major resistance genes $(B s 1, B s 2$, and $B s 3)$ or gene combinations for resistance to bacterial spot of bell peppers (Xanthomonas campestris pv. vesicatoria) in 15 commercial cultivars on disease reduction and yield were studied during 1995 and 1996. Reaction of cultivars to specific races (races 1,2, or 3) of the pathogen corresponded with seed company claims for resistance against these races. Races 1 to 4 were used as initial inoculum in 1995, and races 1 to 6 in 1996 field experiments. Cultivars with no known resistance genes to bacterial spot (e.g., Camelot, Jupiter, and Valiant), a single resistance gene (X3R Camelot, King Arthur), or a combination of $B s 1$ and $B s 3$ genes (Guardian, Sentinel, and Admiral) were severely diseased. Yields were reduced in all inoculated cultivars compared to non-inoculated cultivars used as controls. Although races 4 and 6 caused significant disease in cultivars with only Bsl (King Arthur) or $B s 2$ (X3R Camelot) genes, cultivars with a combination of Bs1 and Bs2 (Boynton Bell, PR93008) had much lower levels of bacterial spot. Roger 4178, a hybrid with a combination of Bsl, $B s 2$, and $B s 3$ genes, had the lowest disease ratings. Overall, race 3 was predominant during 1995, while races 3 and 6 were recovered most frequently in 1996.
\end{abstract}

Managing bacterial diseases of vegetable crops is difficult once they are present. Bacterial spot of bell peppers caused by Xanthomonas campestris pv. vesicatoria (proposed: $X$. axonopodis pv. vesicatoria; $28)$ is a major limiting factor in bell pepper production. Host-plant resistance is an important component of an integrated management program for this disease. Cultivars with host resistance and good acceptable horticultural characteristics generally take years to develop. There are 3 known independent dominant genes $(B s 1, B s 2$, and $B s 3)$ for qualitative resistance to specific races of $X$. campestris pv. vesicatoria $(\mathrm{Xcv})$ in peppers $(4,5,9,12)$. The prevalence of host-differentiated races makes it difficult to manage this disease based only on host resistance $(1,6,13,20-23)$. Furthermore, race shifts can nullify the effectiveness of resistance genes (major genes) when deployed in monoculture $(7,14)$.

Corresponding author: C. S. Kousik

E-mail: kousikcs@unity.ncsu.edu

This research was funded in part by a NRI Competitive Grants Program/USDA Agreement No.9635313-3621, and by the North Carolina Agricultural Research Service. The use of trade names in this publication does not imply endorsement by the North Carolina Agricultural Research Service of the products named or criticism of similar ones not mentioned.

Accepted for publication 20 October 1997.

Publication no. D-1997-1215-03R

(C) 1998 The American Phytopathological Society
To date, 7 races (designated 0 to 6 ) of the pathogen have been characterized on the basis of hypersensitive reaction on three near-isogenic lines of Early Calwonder (ECW), each with a single gene for resistance $(1,6,13,18,20,22,23)$. These near-isogenic lines are ECW-10R (contains resistance gene $B s 1$ ), resistant to races 0,2 , and 5; ECW-20R (Bs2), resistant to races 0 to 3; and ECW-30R (Bs3), resistant to races 0,1 , and $4(13,14,18,20)$. Thus, the currently known genes for resistance to bacterial spot can be overcome by at least one race $(13,14,15,18,20)$, and race 6 can overcome all 3 genes $(22,23)$. The use of pyramids made up of several resistance genes to manage fungal diseases in cereals has been well described (19). In the current study, we determined the presence of major (dominant) resistance genes or gene combinations by phenotypic reactions of commercial hybrids to seven $X$. campestris pv. vesicatoria races. Furthermore, we determined how such genes or gene combinations perform when multiple pathogen races are present in the field.

\section{MATERIAL AND METHODS}

Determining the presence or absence of major resistance genes in cultivars. During 1995 and 1996, 15 commercial cultivars were evaluated, 14 of which were hybrids. Jupiter, a highly susceptible standard, was the only open-pollinated cultivar tested. The presence or absence of the major (dominant) resistance genes $B s 1, B s 2$, $B s 3$, or combinations of them in representative plants of 15 individual cultivars was determined by infiltrating leaves of 38 week-old greenhouse-grown plants with inoculum suspension $\left(10^{8} \mathrm{CFU} / \mathrm{ml}\right)$ of races 0 (Xcv 19), race 1 (Xcv 79), race 2 (Xcv 126), race 3 (Xcv 110), race 4 (Xcv 181 ), race 5 (Xcv 206), and race 6 (Xcv 199) using a needleless syringe in the laboratory. Details of the strains used in these experiments have been described previously (15). This test mainly helps in determining the presence of the 3 major genes for resistance. No attempt was made to assess the cultivars for other quantitative resistance that might occur independent of the major genes. Reaction of the cultivars to the races was observed periodically during a 48-h period, and the presence or absence of a hypersensitive response (HR) or a compatible $(\mathrm{C})$ response was recorded (Table 1). The phenotype and the time required for the HR to occur in response to the different races was also considered in determining the resistance genes (data not presented), as this reaction varies among the interactions of the resistance gene in the plant and corresponding avirulence genes present in the pathogen (18). Reactions of races to the four near-isogenic lines of Early Calwonder were also tested. These experiments were conducted during 1995 and 1996.

Field experiments. The field experiments were conducted at Sandhills Research Station, Jackson Springs, North Carolina, during 1995 and 1996. The same 15 commercial cultivars presented in Table 1 were evaluated in this experiment. Pepper plants were grown and transplanted to the fields according to the standard practices for commercial North Carolina production (24). Transplants were grown in greenhouses for 7 weeks in Styrofoam trays with $2.54-\mathrm{cm}$ (1-inch) cells and 200 cells per tray. Overhead irrigation (1.6 $\mathrm{cm} / \mathrm{h}$ ) was applied to the crop as needed to maintain optimum plant growth.

In 1995, transplants were set on 27 April on bare ground ridges. Each plot consisted of one row on a $97-\mathrm{cm}$ center, with 7 plants of a cultivar per row, spaced $36 \mathrm{~cm}$ apart. Each plot was replicated four times in a randomized complete block design. On 4 May, 4 plants, 1 each inoculated in the greenhouse with race $1,2,3$, or 4 , were transplanted to the center of each plot. Races had the following phenotypic marker: race 1 , rifampicin-resistant $\left(\mathrm{Rif}^{\mathrm{R}}\right.$, $50 \mu \mathrm{g} / \mathrm{ml})$; race 2 , copper $\left(\mathrm{Cu}^{\mathrm{R}}, 200\right.$ $\mu \mathrm{g} / \mathrm{ml})-$ and streptomycin $\left(\mathrm{Sm}^{\mathrm{R}}, 200\right.$ 
$\mu \mathrm{g} / \mathrm{ml})$-resistant; race $3, \mathrm{Cu}^{\mathrm{S}}$ and $\mathrm{Sm}^{\mathrm{S}}$; race $4, \mathrm{Cu}^{\mathrm{R}}(200 \mu \mathrm{g} / \mathrm{ml})$ and $\mathrm{Sm}^{\mathrm{S}}$. These inoculum plants (susceptible cv. Camelot) were inoculated with two strains per race $(15,17)$. The details of the strains used in these studies have been reported previously (15). Groups of inoculated plants (grouped by race) were isolated from each other in the greenhouse by maintaining them in different rooms, and misted occasionally until symptom appearance, prior to transferring to the field. The presence of a specific race on the inoculated plants was verified prior to transferring these plants to the field $(14,15,17)$. Data on disease development on plants in the field were recorded weekly using a 0 to 9 scale described previously $(14,17)$. Diseased leaf samples were collected from each cultivar at 2week intervals, and isolations of the pathogen were made on non-selective yeast dextrose calcium carbonate agar (YDC) to assess the predominant race on each cultivar (20). For bacterial isolations, leaf samples from all four replications for each cultivar were pooled. Single lesions from each of 8 to 10 leaves were excised and macerated in $500 \mu \mathrm{l}$ of sterile distilled water. The resulting suspension was streaked on 2 plates of YDC. Ten isolated single colonies were randomly picked from the YDC plates for each cultivar. Resistance to antibiotics or copper and the race of each of these single colonies was determined as described previously (20). Sampling was done three times during 1995. Mature green peppers were harvested twice, and number and weight of fruit recorded.

In addition, a similar experiment with two replications and 5 plants per cultivar per plot was conducted approximately 300 $\mathrm{m}$ from the inoculated site at a site which was not inoculated (check).
During 1996, a similar trial with the same 15 cultivars was conducted at a site where peppers had not been grown for at least 2 years. Plants were transplanted on 1 May. Plots were single rows on ridges on a 112 -cm center, containing 9 plants spaced $36 \mathrm{~cm}$ apart within each row. Cultivars

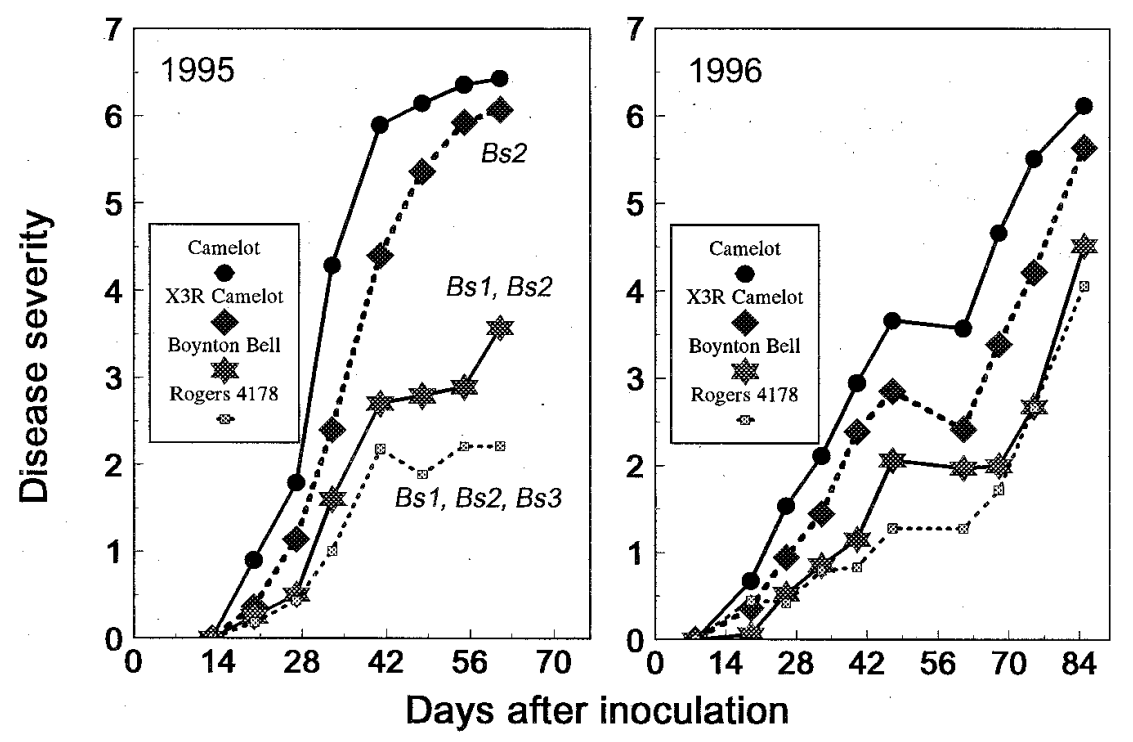

Fig 1. Disease development in bell pepper cultivar experiments conducted at Sandhills Research Station, Jackson Springs, North Carolina, during 1995 and 1996. Races 1 to 4 were used as inoculum in 1995 and races 1 to 6 in 1996. Field plots were inoculated on 4 May 1995 and 14 May 1996. Cultivar Camelot is susceptible to all known races. X3R Camelot has resistance gene Bs2 and is resistant to races 0 to 3. Boynton Bell has resistance genes $B s 1$ and $B s 2$ and is resistant to races 0 to 3 and 5. Rogers 4178 has resistance genes $B s 1, B s 2$, and $B s 3$, and is resistant to races 0 to 5 . Race 6 causes disease on all of these cultivars.

Table 1. Reaction of bell pepper cultivars ${ }^{\mathrm{x}}$ and near-isolines to races 0 to 6 of Xanthomonas campestris pv. vesicatoria and the presence of different major resistance genes

\begin{tabular}{|c|c|c|c|c|c|c|c|c|}
\hline \multirow[b]{2}{*}{ Cultivar/isolines } & \multicolumn{7}{|c|}{ Reaction to races } & \multirow[b]{2}{*}{ Putative major resistance genes ${ }^{\mathrm{y}}$} \\
\hline & $\mathbf{0}$ & 1 & 2 & 3 & 4 & 5 & 6 & \\
\hline ECW & $\mathrm{C}$ & $\mathrm{C}$ & $\mathrm{C}$ & $\mathrm{C}$ & $\mathrm{C}$ & $\mathrm{C}$ & $\mathrm{C}$ & $\ldots^{\mathrm{z}}$ \\
\hline ECW-10R & HR & $\mathrm{C}$ & HR & $\mathrm{C}$ & $\mathrm{C}$ & $\mathrm{HR}$ & $\mathrm{C}$ & $B s 1$ \\
\hline ECW-20R & HR & HR & HR & HR & $\mathrm{C}$ & $\mathrm{C}$ & $\mathrm{C}$ & $B s 2$ \\
\hline ECW-30R & HR & HR & $\mathrm{C}$ & $\mathrm{C}$ & HR & $\mathrm{C}$ & $\mathrm{C}$ & $B s 3$ \\
\hline Baron & $\mathrm{C}$ & $\mathrm{C}$ & $\mathrm{C}$ & $\mathrm{C}$ & $\mathrm{C}$ & $\mathrm{C}$ & $\mathrm{C}$ & $\ldots$ \\
\hline Valiant & $\mathrm{C}$ & $\mathrm{C}$ & $\mathrm{C}$ & $\mathrm{C}$ & $\mathrm{C}$ & $\mathrm{C}$ & $\mathrm{C}$ & $\ldots$ \\
\hline Camelot & $\mathrm{C}$ & $\mathrm{C}$ & $\mathrm{C}$ & $\mathrm{C}$ & $\mathrm{C}$ & $\mathrm{C}$ & $\mathrm{C}$ & $\ldots$ \\
\hline Jupiter & $\mathrm{C}$ & $\mathrm{C}$ & $\mathrm{C}$ & $\mathrm{C}$ & $\mathrm{C}$ & $\mathrm{C}$ & $\mathrm{C}$ & $\ldots$ \\
\hline King Arthur & HR & $\mathrm{C}$ & $\mathrm{HR}$ & $\mathrm{C}$ & $\mathrm{C}$ & $\mathrm{HR}$ & $\mathrm{C}$ & $B s 1$ \\
\hline X3R Camelot & HR & HR & HR & HR & $\mathrm{C}$ & $\mathrm{C}$ & $\mathrm{C}$ & $B s 2$ \\
\hline Admiral & HR & HR & HR & $\mathrm{C}$ & $\mathrm{HR}$ & $\mathrm{HR}$ & $\mathrm{C}$ & $B s 1, B s 3$ \\
\hline Sentinel & HR & HR & HR & $\mathrm{C}$ & $\mathrm{HR}$ & HR & $\mathrm{C}$ & $B s 1, B s 3$ \\
\hline Guardian & HR & HR & HR & $\mathrm{C}$ & HR & HR & $\mathrm{C}$ & $B s 1, B s 3$ \\
\hline Boynton Bell & HR & HR & HR & HR & $\mathrm{C}$ & $\mathrm{HR}$ & $\mathrm{C}$ & $B s 1, B s 2$ \\
\hline PR300-4 & HR & HR & HR & HR & $\mathrm{C}$ & HR & $\mathrm{C}$ & $B s 1, B s 2$ \\
\hline PR300-6 & HR & HR & HR & HR & $\mathrm{C}$ & HR & $\mathrm{C}$ & $B s 1, B s 2$ \\
\hline PR9300-5 & HR & HR & HR & HR & $\mathrm{C}$ & HR & $\mathrm{C}$ & $B s 1, B s 2$ \\
\hline PR9300-8 & HR & HR & HR & HR & $\mathrm{C}$ & HR & $\mathrm{C}$ & $B s 1, B s 2$ \\
\hline Rogers 4178 & HR & HR & HR & HR & $\mathrm{HR}$ & $\mathrm{HR}$ & $\mathrm{C}$ & $B s 1, B s 2, B s 3$ \\
\hline Resistance genes that elicit & Bs1 & & Bs 1 & & & Bsl & & \\
\hline HR to the above races & $B s 2$ & $B s 2$ & $B s 2$ & $B s 2$ & & & $\ldots$ & \\
\hline & $B s 3$ & Bs3 & & & Bs3 & & & \\
\hline
\end{tabular}

\footnotetext{
${ }^{\mathrm{x}}$ Leaves of each cv. ( 8 weeks old) were infiltrated with inoculum suspension $\left(10^{8} \mathrm{CFU} / \mathrm{ml}\right)$ of races 0 to 6 and observations for compatible (C, disease reaction) or hypersensitive reaction (HR, resistant reaction) were recorded during a 48-h period. The phenotype and the time re quired for the HR to occur in response to the different races was also considered in determining the resistance genes (data not presented). This varies among the interactions of the resistance gene in the plant and corresponding avirulence genes present in the pathogen (18).

$\mathrm{y}$ The presence of the major resistance genes was determined based on the phenotypic reaction of the cultivars to races 0 to 6 . However, this technique will not detect the presence of other varying levels of quantitative resistance traits.

${ }^{\mathrm{z}} \ldots=$ no major resistance gene detected.
} 
were replicated four times in a randomized complete block design. On 14 May, inoculum plants infected with races 1 to 6 were planted in the center of each plot. Inoculum plants were prepared as described above. Disease assessment and race determination were carried out as in 1995. Samples of diseased leaves were collected three times. The noninoculated check plot did not develop properly due to unknown reasons, and hence no comparisons between inoculated and diseasefree plots could be made in 1996.

Statistical analyses. Areas under the disease progress curves (AUDPC) were calculated as described by Campbell and Madden (2). For each year, one-way analysis of variance was performed on the AUDPC values. Means were separated using the Waller-Duncan $k$-ratio $t$ tests. In addition, specific non-orthogonal contrasts were estimated to compare the effects of individual genes and gene combinations in different cultivars. The cumulative effects of $B s 1$ and $B s 2$ in five pepper hybrids were contrasted with the effects of $B S 1$ in King Arthur and Bs2 in X3R Camelot and the cultivars without any major genes. All statistical analyses were performed using the SAS statistical package (Ver 6.10, SAS Institute, Cary, NC).

Table 2. Resistance genes present in bell pepper cultivars, area under the disease progress curve (AUDPC), yield/plant for inoculated plots, control yield/plant for non-inoculated plots, and race distribution in a cultivar experiment inoculated with races 1 to 4 of Xanthomonas campestris pv. vesicatoria in 1995

\begin{tabular}{|c|c|c|c|c|c|c|c|c|c|}
\hline \multirow[b]{2}{*}{ Cultivar } & \multirow{2}{*}{$\begin{array}{l}\text { Putative major } \\
\text { resistance genes }^{w}\end{array}$} & \multirow[b]{2}{*}{$\operatorname{AUDPC}^{\mathbf{x}}$} & \multirow[b]{2}{*}{ Yield/plant $(g)^{y}$} & \multirow{2}{*}{$\begin{array}{c}\text { Control } \\
\text { yield/plant (g) }\end{array}$} & \multicolumn{4}{|c|}{ Race distribution $(\%)^{\mathrm{v}}$} & \multirow{2}{*}{$\begin{array}{c}\text { Number of } \\
\text { colonies tested }\end{array}$} \\
\hline & & & & & 1 & 2 & 3 & 4 & \\
\hline Camelot & $\ldots$ & $193 \mathrm{a}^{\mathrm{z}}$ & $28 \mathrm{~d}$ & $556 \mathrm{~d}$ & 0 & 18 & 77 & 7 & 22 \\
\hline Jupiter & $\ldots$ & $193 \mathrm{a}$ & $20 \mathrm{~d}$ & 812 bcd & 0 & 0 & 95 & 5 & 21 \\
\hline Baron & $\ldots$ & $192 \mathrm{ab}$ & $49 \mathrm{~d}$ & $\ldots$ & 0 & 0 & 100 & 0 & 25 \\
\hline Guardian & $B s 1, B s 3$ & $182 \mathrm{ab}$ & $28 \mathrm{~d}$ & 817 abcd & 0 & 0 & 100 & 0 & 20 \\
\hline King Arthur & Bs 1 & $179 a b$ & $65 \mathrm{~d}$ & $\ldots$ & 0 & 0 & 100 & 0 & 25 \\
\hline Admiral & $B s 1, B s 3$ & $178 \mathrm{ab}$ & $81 \mathrm{~d}$ & $763 \mathrm{~cd}$ & 0 & 0 & 100 & 0 & 24 \\
\hline Sentinel & $B s 1, B s 3$ & $174 \mathrm{ab}$ & $73 \mathrm{~d}$ & $1114 \mathrm{a}$ & 0 & 0 & 100 & 0 & 21 \\
\hline Valiant & $\ldots$ & $156 \mathrm{c}$ & $235 \mathrm{c}$ & $741 \mathrm{~cd}$ & 0 & 27 & 68 & 5 & 22 \\
\hline X3R Camelot & $B s 2$ & $153 \mathrm{c}$ & $142 \mathrm{~cd}$ & $873 \mathrm{abc}$ & 0 & 10 & 0 & 90 & 29 \\
\hline PR9300-5 & $B s 1, B s 2$ & $104 \mathrm{~d}$ & $255 \mathrm{c}$ & $924 \mathrm{abc}$ & 0 & 0 & 13 & 88 & 24 \\
\hline PR9300-8 & $B s 1, B s 2$ & $91 \mathrm{de}$ & $429 \mathrm{~b}$ & $1069 a b$ & 0 & 0 & 78 & 22 & 23 \\
\hline Boynton Bell & $B s 1, B s 2$ & $85 \mathrm{e}$ & $446 \mathrm{~b}$ & $1077 \mathrm{ab}$ & 0 & 3 & 83 & 14 & 29 \\
\hline PR300-6 & $B s 1, B s 2$ & $85 \mathrm{e}$ & $437 \mathrm{~b}$ & $919 a b c$ & 0 & 0 & 33 & 67 & 18 \\
\hline PR300-4 & $B s 1, B s 2$ & $80 \mathrm{e}$ & $425 \mathrm{~b}$ & $1101 \mathrm{ab}$ & 0 & 0 & 11 & 89 & 18 \\
\hline Rogers 4178 & $B s 1, B s 2, B s 3$ & $61 \mathrm{f}$ & $731 \mathrm{a}$ & $910 \mathrm{a}$ & 0 & 0 & 83 & 17 & 24 \\
\hline $\begin{array}{l}\text { Total distribution } \\
\text { of races }\end{array}$ & & & & & 0 & 4 & 71 & 25 & 370 \\
\hline
\end{tabular}

${ }^{\mathrm{v}}$ Predominance of individual races was determined by isolating bacteria from diseased leaf samples and testing their reactions on pepper differentials ECW, ECW-10R, ECW-20R, and ECW-30R.

${ }^{\text {w }}$ Presence of major resistance genes was determined by infiltrating with races 0 to 6 and observing for hypersensitive response (HR) as described in Table $1 . \ldots=$ no major resistance genes detected.

${ }^{x}$ AUDPC was calculated using eight weekly observations using a 0 to 9 disease rating scale, where $0=$ no diseased leaves, $4=21$ to $35 \%$ diseased leave, $7=65$ to $80 \%$ diseased leaves, and $9=100 \%$ diseased leaves, plant dying or dead.

y Yield/plant was calculated for the control plots (disease-free) for comparison with yield/plant in inoculated plot.

${ }^{\mathrm{z}}$ Means followed by the same letter within columns are not significantly different based on the Waller-Duncan $k$-ratio $(k=100) t$ tests $(\alpha=0.05)$.

Table 3. Resistance genes present in bell pepper cultivars, area under the disease progress curve (AUDPC), yield/plant, and race distribution in a cultivar experiment inoculated with races 1 to 6 of Xanthomonas campestris pv. vesicatoria in 1996

\begin{tabular}{|c|c|c|c|c|c|c|c|c|c|c|}
\hline \multirow[b]{2}{*}{ Cultivar } & \multirow{2}{*}{$\begin{array}{l}\text { Putative major } \\
\text { resistance genes }^{w}\end{array}$} & \multirow[b]{2}{*}{ AUDPC $^{x}$} & \multirow[b]{2}{*}{ Yield/plant $(g)^{y}$} & \multicolumn{6}{|c|}{ Race distribution $(\%)^{\mathrm{v}}$} & \multirow{2}{*}{$\begin{array}{l}\text { Number of } \\
\text { colonies tested }\end{array}$} \\
\hline & & & & 1 & 2 & 3 & 4 & 5 & 6 & \\
\hline Camelot & $\ldots$ & $241 \mathrm{a}^{\mathrm{z}}$ & 385 ef & 23 & 12 & 62 & 4 & 0 & 0 & 26 \\
\hline Baron & $\ldots$ & $230 a b$ & $229 \mathrm{f}$ & 29 & 0 & 14 & 7 & 0 & 50 & 28 \\
\hline Jupiter & $\cdots$ & $220 \mathrm{ab}$ & $465 \mathrm{def}$ & 22 & 11 & 48 & 0 & 15 & 4 & 27 \\
\hline Admiral & $B s 1, B s 3$ & $217 \mathrm{ab}$ & 394 ef & 0 & 0 & 80 & 0 & 0 & 20 & 20 \\
\hline Guardian & $B s 1, B s 3$ & $213 \mathrm{ab}$ & $392 \mathrm{ef}$ & 0 & 0 & 94 & 0 & 0 & 6 & 17 \\
\hline Valiant & $\ldots$ & $207 \mathrm{bc}$ & $527 \mathrm{de}$ & 21 & 16 & 47 & 5 & 0 & 11 & 19 \\
\hline King Arthur & Bs 1 & $204 b c$ & $456 \mathrm{def}$ & 18 & 0 & 61 & 0 & 0 & 21 & 28 \\
\hline Sentinel & $B s 1, B s 3$ & $200 \mathrm{bc}$ & $513 \mathrm{de}$ & 0 & 0 & 100 & 0 & 0 & 0 & 25 \\
\hline X3R Camelot & Bs2 & $176 \mathrm{~cd}$ & 608 cde & 0 & 9 & 0 & 18 & 46 & 27 & 22 \\
\hline PR9300-8 & $B s 1, B s 2$ & $158 \mathrm{de}$ & $697 \mathrm{bcd}$ & 9 & 9 & 17 & 26 & 0 & 39 & 23 \\
\hline PR9300-5 & $B s 1, B s 2$ & 135 ef & 848 abc & 5 & 0 & 20 & 5 & 0 & 70 & 20 \\
\hline PR300-6 & $B s 1, B s 2$ & $122 \mathrm{fg}$ & $847 a b c$ & 0 & 0 & 4 & 4 & 0 & 93 & 29 \\
\hline Boynton Bell & $B s 1, B s 2$ & $118 \mathrm{fg}$ & $997 \mathrm{a}$ & 0 & 0 & 27 & 50 & 0 & 23 & 22 \\
\hline PR300-4 & $B s 1, B s 2$ & $117 \mathrm{fg}$ & $925 \mathrm{ab}$ & 4 & 0 & 4 & 26 & 0 & 67 & 27 \\
\hline Rogers 4178 & $B s 1, B s 2, B s 3$ & $100 \mathrm{~g}$ & $1,027 \mathrm{a}$ & 0 & 42 & 4 & 0 & 0 & 54 & 26 \\
\hline $\begin{array}{l}\text { Total distribution } \\
\text { of races }(\%)\end{array}$ & & & & 9 & 7 & 38 & 9 & 4 & 34 & 389 \\
\hline
\end{tabular}

v Predominance of individual races was determined by isolating bacteria from diseased leaf samples and testing their reactions on pepper differentials ECW, ECW-10R, ECW-20R, and ECW-30R.

${ }^{\text {w }}$ Presence of resistance genes was determined by infiltrating leaves with races 0 to 6 and observing for hypersensitive response (HR) during a 48-h period as described in Table $1 . \ldots=$ no major resistance gene detected.

$\times$ AUDPC was calculated from 10 weekly observations using a 0 to 9 disease rating scale, where $0=$ no diseased leaves, $4=21$ to $35 \%$ diseased leave, $7=$ 65 to $80 \%$ diseased leaves, and $9=100 \%$ diseased leaves, plant dying or dead.

y Yield/plant is based on three harvests.

${ }^{\mathrm{z}}$ Means followed by the same letter within columns are not significantly different, based on the Waller-Duncan $k$-ratio $(k=100) t$ tests $(\alpha=0.05)$. 


\section{RESULTS}

The current tests confirmed the presence of specific resistance genes or gene combinations in commercial hybrid pepper cultivars (Table 1). During 1995, bacterial spot progressed rapidly and susceptible cultivars (e.g., Camelot and Jupiter) were severely diseased (Fig. 1). Plants with single major resistance gene Bsl (King Arthur) or Bs2 (X3R Camelot) also were severely effected. Similarly, cultivars with $B s 1$ and $B s 3$ genes (Guardian) were also heavily damaged (Table 2). In contrast, plants with $B s 1$ and $B s 2$ (e.g., Boynton Bell or PR9300-6) or Bs1, Bs2, and Bs3 (e.g., Rogers 4178) genes in combination performed well under heavy disease pressure. Rogers 4178 had the lowest disease ratings and the largest yields. Isolations revealed that race 3 was predominant during the 1995 season on most cultivars. Race 4 was recovered most frequently from X3R Camelot and PR9300-4.

In 1996, bacterial spot development was slow during the early part of the season. However, by late June all susceptible cultivars were severely diseased. X3R Camelot (Bs2) had significantly less disease and greater yield than Camelot, but significantly more disease than cultivars with $B s 1$ and Bs2 (Table 3). Rogers 4178 (Bs1, Bs2, and $B s 3$ ) had significantly less disease than cultivars with $B s l$ and $B s 3$ (Guardian), $B s l$ (King Arthur), and Bs2 (X3R Camelot). However, the disease level on Rogers 4178 was not significantly different from some of the cultivars with a combination of $B s l$ and $B s 2$ (e.g., Boynton Bell). Overall, race 3 and race 6 were predominant in this test. Race 3 prevailed on cultivars which had no specific resistance gene against it. These included Camelot, King Arthur (Bs1), and Sentinel (BsI and Bs3). Infections on PR9300-6 (Bs1 and $B s 2$ ) were mostly due to race 6 . Races 4, 5, and 6 were found on X3R Camelot.

Combining $B s 1$ and $B s 2$ resistance genes provided significantly greater protection than that provided by $B s 2$ gene alone during both years (Table 4). Bs2 alone was better than having no resistance genes. The effects of combining Bs1 and Bs2 appeared to be cumulative. Combination of 3 genes offered improved protection against race 6 compared with a combination of 2 genes (Table 4).

During both years, the cultivar Camelot had the lowest yield and Rogers 4178 had the highest yield in the inoculated plots. In 1995 , cultivar Sentinel and 8 other cultivars had higher yields in the non-inoculated plots among the 15 cultivars tested. Significant correlations $(P=0.0001)$ between AUDPC and yield-per-plant were observed in these experiments during 1995 $\left(R^{2}=0.81\right)$ and $1996\left(R^{2}=0.79\right)$.

\section{DISCUSSION}

The presence of resistance to bacterial spot of peppers was described by Horsfall in 1939 (10). Resistance gene Bsl was reported in 1963 (5), Bs2 in 1984 (4), and $B s 3$ in 1985 (12). Resistance to bacterial spot in commercial peppers has been derived from 1 or more of these 3 genes for more than 30 years. This suggests that finding and incorporating resistance into bell pepper while maintaining good horticultural characteristics is difficult, and it would be advantageous to use these 3 genes and any newly discovered ones in the most durable manner. Although the $B s 1$ gene for resistance to race 2 was reported in 1963 (5), cultivars containing Bsl were not released for commercial use at that time because of fear that race 1 epidemics would negate the control by the $B s 1$ gene $(6,9)$. Few, if any, commercial hybrids with only $B s 3$ were developed, mainly because of the threat from race 2. Hybrids with only $B s 3$ are not available, and therefore were not used in this study. Each of the 3 major genes can be overcome by at least one naturally occurring race of the bacterial spot pathogen $(13,14,15,18,20,22,23)$. In the present study, we looked at the deployment of the major genes individually and in pyramids in commercial cultivars. Interestingly, a cultivar with resistance genes Bs1 and Bs2 was described in 1984 (3); however, at that time the effect of the combination of these 2 genes on a race such as 4 or 6 was not known, since these races have been described only very recently $(1,13,22,23)$.

Sixfold yield reductions compared to disease free controls were observed for inoculated X3R Camelot plots in 1995 (Table 2). The gene $B s 2$ by itself thus provided little value for the management of bacterial spot. Races that overcome gene $B s 2$ for resistance and cause disease and yield loss need to be taken into account in breeding for disease resistance and use of other disease management strategies (15). Despite the ability of race 4 and 6 strains to individually overcome resistance genes $B s 1$ and $B s 2$, pyramiding these 2 genes offered improved bacterial spot control; still, twofold yield reductions were observed for those cultivars with $B s 1$ and $B s 2$ genes. Race 3 strains severely damaged cultivars with $B s 1$ and $B s 3$ genes. Combination of the 3 resistance genes $B s 1, B s 2$, and $B s 3$ provided slightly better protection compared to only the 2 genes $B s 1$ and $B s 2$ against race 6 . The cost and time involved in the development of commercially acceptable cultivars with 2 resistance genes compared to cultivars with 3 genes, and the amount of relative protection they offer, should be considered in breeding new va-

Table 4. Estimated contrasts for comparison of areas under the disease progress curves (AUDPC ${ }^{y}$ ) on bell pepper cultivars with a combination of different major resistance ${ }^{\mathrm{z}}$ genes to Xanthomonas campestris pv. vesicatoria

\begin{tabular}{|c|c|c|c|c|}
\hline Contrast & Estimate & Contrast SS & $F$ value & $\operatorname{Pr}>F$ \\
\hline \multicolumn{5}{|l|}{1995} \\
\hline$B s 1$ vs. None & $4.3 \pm 8.6$ & 58.9 & 0.25 & 0.6187 \\
\hline$B s 2$ vs. None & $30.9 \pm 8.6$ & 3059.4 & 13.05 & 0.0008 \\
\hline$B s 1$ and $B s 2$ vs. None & $94.7 \pm 5.1$ & 79702.3 & 339.91 & 0.0001 \\
\hline$B s 1$ and $B s 3$ vs. None & $5.2 \pm 5.9$ & 184.4 & 0.79 & 0.3800 \\
\hline$B s 1, B s 2$, and $B s 3$ vs. None & $122.6 \pm 8.6$ & 48097.5 & 205.12 & 0.0001 \\
\hline$B s 2$ vs. $B s 1$ and $B s 2$ & $63.8 \pm 8.4$ & 13556.0 & 57.81 & 0.0001 \\
\hline$B s 1$ and $B s 2$ vs. $B s 1, B s 2$, and $B s 3$ & $27.9 \pm 8.4$ & 2596.0 & 11.07 & 0.0018 \\
\hline Cumulative effects of $B s 1$ and $B s 2$ & $59.5 \pm 12.0$ & 5776.4 & 24.63 & 0.0001 \\
\hline \multicolumn{5}{|l|}{1996} \\
\hline Bsl vs. None & $20.0 \pm 13.4$ & 1275.3 & 2.21 & 0.1444 \\
\hline$B s 2$ vs. None & $48.3 \pm 13.4$ & 7449.2 & 12.10 & 0.0008 \\
\hline$B s 1$ and $B s 2$ vs. None & $94.4 \pm 8.1$ & 79286.5 & 137.28 & 0.0001 \\
\hline$B s 1$ and $B s 3$ vs. None & $14.4 \pm 9.2$ & 1416.6 & 2.45 & 0.1245 \\
\hline$B s 1, B s 2$, and $B s 3$ vs. None & $129.9 \pm 15.2$ & 42028.8 & 72.77 & 0.0001 \\
\hline$B s 2$ vs. $B s 1$ and $B s 2$ & $46.2 \pm 13.2$ & 7113.7 & 12.32 & 0.0010 \\
\hline$B s 1$ and $B s 2$ vs. $B s 1, B s 2$, and $B s 3$ & $35.4 \pm 15.0$ & 3229.7 & 5.59 & 0.0225 \\
\hline Cumulative effects of $B s 1$ and $B s 2$ & $26.2 \pm 18.8$ & 1123.6 & 1.95 & 0.1701 \\
\hline
\end{tabular}

y AUDPC was calculated as described previously (Campbell and Madden, 1990). AUDPCs are based on 8 weekly observations in 1995 and 10 in 1996 using a 0 to 9 disease rating scale, where $0=$ no diseased leaves, $4=21$ to $35 \%$ diseased leaves, $7=65$ to $80 \%$ diseased leaves, and $9=100 \%$ diseased leaves, plant dying or dead.

${ }^{\mathrm{z}}$ The major resistance genes in the cultivars were determined as described in Table 1. 
rieties. In recent controlled greenhouse studies with near-isolines of ECW inoculated with race 6; ECW-13R ( $B s 1$ and $B s 3$ ) and ECW-123R (Bs1, Bs2, and Bs3) had significantly less disease compared to ECW-10R, ECW-20R, and ECW-30R (16). In the same study, ECW-12R (Bsl and $B s 2$ ) had significantly less disease compared to ECW, ECW-10R, and ECW-20R when inoculated with race 4 (16). Pyramiding may very well be the best option for pepper growers in the southeast who face a number of races in a given season. Though gene pyramids seem to provide more protection than single genes, chemical sprays likely will continue to be needed to provide adequate protection to maximize yield.

The commercial cultivars used in this study were mainly hybrids and not isolines. There may be some level of quantitative resistance (horizontal resistance) present in specific cultivars, and such resistance may play a role in providing some of the observed resistance attributed to gene pyramids. The infiltration technique used to detect the presence of the major resistance genes $B s 1, B s 2$, and $B s 3$ would not detect other quantitative resistance traits present in the commercial cultivars which may also play a role in overall resistance. However, based on distribution of the races on individual commercial hybrids in the current experiments, it appears that the major genes account for a major portion of the resistance currently available. Variations in levels of quantitative resistance in some cultivars without any of the 3 major genes has been described (8). Among the 4 cultivars without any major genes for resistance in the present study, few differences were observed in susceptibility. Similarly small differences in disease severity among cultivars has been reported previously (11). However, cultivar Valiant, which had no detectable major resistance gene, had significantly lower AUDPC values than the other similar cultivars without major resistance genes (e.g., Camelot). Although Valiant had lower AUDPC values than Camelot or Baron, it failed to provide adequate disease protection, and significant yield loss compared to the non-inoculated plots was recorded.

In these field experiments, the disease pressure was very high because the plots were artificially inoculated and conditions were conducive for development of bacterial spot. The abundance of inoculum generated on susceptible cultivars possibly also resulted in interplot interference effects. The plots were completely randomized within each block, and we had inoculated each of the plots similarly with all the races to reduce the risk of interplot interference. It is possible that the abundance of inoculum in the area could also have masked the benefits of resistance in some cultivars, particularly those with different gene combinations.
Strains of the bacterial spot pathogen have been shown to shift races within a season in the field when genotypes with a single gene for resistance were deployed (14). Such race changes have also been observed in laboratory experiments (7). During the fruit production part of the season in 1995 , only races 2,3 , or 4 were isolated from the commercial hybrids. However, we isolated strains of race 6 from Rogers 4178 near the end of the fruit production period. It may be that race changes/shifts occurred during the course of the experiments in this cultivar with the 3 genes. Because of the pathogens' ability to rapidly overcome major genes $(7,14)$, breeding for bacterial spot resistance may ultimately dictate incorporation of quantitative resistance and major resistance gene pyramids in commercial cultivars.

The predominance of races on the cultivars was to an extent related to the resistance genes present in them. During 1996, races that overcome the $B s 2$ gene were predominant on cultivars with the $B s 2$ gene. Race 3 was generally more prevalent on cultivars with no resistance genes, or cultivars with $B s 1$, or a combination of $B s l$ and $B s 3$. Race 6 also was isolated from 14 of the 16 cultivars in 1996. During 1995 and 1996, race 3 was isolated from 15 of the 16 cultivars. Race 3 also was common on Rogers 4178 and Boynton Bell in 1995. These two cultivars should have been resistant to race 3 , due to the presence of the $B s 2$ gene. During the past few years, we have observed the presence of race 3 in diseased samples from commercial pepper fields where cultivars with resistance gene $B s 2$ were grown (21). The reason for this is unclear. The effects of high temperature (21) and water soaking (25) have been reported to inhibit the HR in plants containing single major resistance genes. Overall, race 3 appears to be highly aggressive. In other studies, race 3 was observed to emerge as the dominant race in a mixture of 1,2 , and 3 (17), while race 6 did so in a mixture of 4,5 , and 6 (15). In greenhouse experiments, strains of races 1 , 3,4 , and 6 were found to cause similar levels of disease on susceptible cultivars (15). Further controlled studies are needed to determine the interaction between individual races and the resistance genes and gene pyramids.

The demand for high quality produce dictates that an integrated program for bacterial spot control, including host-plant resistance and judicious use of chemical sprays, be used. The recent developments in cloning major genes for resistance to bacterial pathogens (27) and progress in cloning of the Bs2 gene (26) may enable breeders to move major genes for resistance to specific races into genotypes with quantitative resistance. Combined with timely chemical applications, bacterial spot might be managed effectively and consistently.
ACKNOWLEDGMENTS

We thank D. Elwell, W. Pollard, T. Abernathy, and the staff at Sandhills Research Station for their assistance; and M. Gumpretz for help with statistical analysis.

\section{LITERATURE CITED}

1. Bouzar, H., Jones, J. B., Stall, R. E., Hodge, N. C., Minsavage, G. V., Benedict, A. A., and Alvarez, A. M. 1994. Physiological, chemical, serological, and pathogenic analyses of a world wide collection of Xanthomonas campestris pv. vesicatoria strains. Phytopathology 84:663-671.

2. Campbell, C. L., and Madden, L. V. 1990 Introduction to plant disease epidemiology. John Wiley and Sons, New York.

3. Cook, A. A. 1984. Florida XVR 3-25 Bell Pepper. HortScience 19(5):735.

4. Cook, A. A., and Guevara, Y. G. 1984. Hypersensitivity in Capsicum chacoense to race 1 of the bacterial spot pathogen of pepper. Plant Dis. 68:329-330.

5. Cook, A. A., and Stall, R. E. 1963 Inheritance of resistance in pepper to bacterial spot. Phytopathology 53:1060-1062.

6. Cook, A. A., and Stall, R. E. 1982. Distribution of races of Xanthomonas vesicatoria pathogenic on pepper. Plant Dis. 66:388-389.

7. Dahlbeck, D., and Stall, R. E. 1979. Mutations for change of race in cultures of Xanthomonas vesicatoria. Phytopathology 69:634-636.

8. Hibberd, A. M. 1989. Quantitative resistance to bacterial leaf spot of pepper compared in mono and polycyclic disease progress tests. Pages 213-219 in: Tomato and Pepper Production in the Tropics: Integrated Management Practices. S. K Green, T. D. Griggs, and B. T. McLean, eds. AVRDC, Shanhua, Tainan.

9. Hibberd, A. M., Stall, R. E., and Bassett, M. J. 1987. Different phenotypes associated with incompatible races and resistance genes in bacterial spot disease of pepper. Plant Dis. 71:1075-1078.

10. Horsfall, J. G., and McDonald, A. D. M 1940. Variety susceptibility of peppers to bacterial spot. Plant Dis. Rep. 24:34-36.

11. Jones, J. B., and Jones, J. P. 1986. Control of Xanthomonas campestris pv. vesicatoria in Florida. Pages 3-8 in Florida Pepper Institute, Vegetable Crops Extension Report. VEC 863. W. M. Stall, ed. Institute of Food and Agricultural Sciences, University of Florida.

12. Kim, B-S., and Hartmann, R. W. 1985. Inheritance of a gene (Bs3) conferring hypersensitive resistance to Xanthomonas campestris pv. vesicatoria in pepper (Capsicum annuum). Plant Dis. 69:233-235.

13. Kousik, C. S., and Ritchie, D. F. 1995. Isolation of pepper races 4 and 5 of Xanthomonas campestris pv. vesicatoria from diseased peppers in southeastern U.S. fields. Plant Dis. 79:540.

14. Kousik, C. S., and Ritchie, D. F. 1996. Race shift in Xanthomonas campestris pv. vesicatoria within a season in field grown peppers. Phytopathology 86:952-958.

15. Kousik, C. S., and Ritchie, D. F. 1996. Disease potential of pepper bacterial spot pathogen races that overcome the $B s 2$ gene for resistance. Phytopathology 86:1336-1343.

16. Kousik, C. S., and Ritchie, D. F. 1997. Effect of pyramids of defeated major resistance genes on bell pepper bacterial spot development. (Abstr.) Phytopathology 87:S54

17. Kousik, C. S., Sanders, D. C., and Ritchie, D. F. 1996. Mixed genotypes combined with copper sprays to manage bacterial spot of bell peppers. Phytopathology 86:502-508.

18. Minsavage, G. V., Dahlbeck, D., Whalen, M. C., Kearney, B., Bonas, U., Staskawicz, B. J., and Stall R. E. 1990. Gene-for-gene relation- 
ships specifying disease resistance in Xanthomonas campestris pv. vesicatoria-pepper interactions. Mol. Plant-Microbe Interact. 3:41-47.

19. Pedersen, W. L., and Leath, S. 1988. Pyramiding major genes for resistance to maintain residual effects. Annu. Rev. Phytopathol. 26:369-378.

20. Ritchie, D. F., and Dittapongpitch, V. 1991. Copper- and streptomycin-resistant strains and host differentiated races of Xanthomonas campestris $p v$. vesicatoria in North Carolina. Plant Dis. 75:733-736.

21. Romero, A. M., Kousik, C. S., and Ritchie, D. F. 1996. Characteristics of race 3 strains of the bacterial spot pathogen isolated from pepper. Pages 61-62 in: Proc. Nat. Pepper Conf.
D. N. Maynard, ed. Naples, FL.

22. Sahin, F., and Miller, S. A. 1995. First report of pepper race 6 of Xanthomonas campestris pv. vesicatoria, causal agent of bacterial spot of bell pepper. Plant Dis. 79:1188.

23. Sahin, F., and Miller, S. A. 1996. Characterization of Ohio strains of Xanthomonas campestris pv. vesicatoria, causal agent of bacterial spot of bell pepper. Plant Dis. 80:773778.

24. Sanders, D. C., Averre, C. W., Sorensen, K. A., Estes, E. A., Beasley, E. O., and Bonanno, A. R. 1988. Commercial pepper production in North Carolina. N.C. Coop. Ext. Serv. AG387.

25. Stall, R. E., and Cook, A. A. 1979. Evidence that bacterial contact with the plant cell is necessary for the hypersensitive reaction but not the susceptible reaction. Physiol. Plant Pathol. 14:77-84

26. Stall, R. E., Minsavage, G. V., Cook, A., Basset, M., Thai, T., Dahlbeck, D., and Staskawicz, B. J. 1995. Induction of mutants of Capsicum annuum for loss of hypersensitivity to strains of Xanthomonas campestris pv. vesicatoria containing avrBs2. (Abstr.) Phytopathology 85:1140.

27. Staskawicz, B. J., Ausubel, F. M., Baker, B. J., Ellis, J. G., and Jones, J. D. G. 1995. Molecular genetics of plant disease resistance. Science 268:661-667.

28. Vauterin, L., Hoste, B., Kersters, K., and Swings, J. 1995. Reclassification of Xantho monas. Int. J. Syst. Bacteriol. 45(3):472-489. 